\title{
Review of the development of the Peregrine Falcon (Falco peregrinus) population in Hungary between 1997 and 2018
}

\author{
Mátyás Prommer ${ }^{1 *} \&$ János BAGYURA ${ }^{2}$
}

Received: December 19, 2018 - Revised: December 24, 2018 -Accepted: December 25, 2018

This is a contribution submitted to the Proceedings of the World Conference on the Peregrine Falcon in Budapest in September 2017.

Prommer, M. \& Bagyura, J. 2018. Review of the development of the Peregrine Falcon (Falco peregrinus) population in Hungary between 1997 and 2018. - Ornis Hungarica 26(2): 2-11.

DOI: $10.1515 /$ orhu-2018-011

\begin{abstract}
Peregrine Falcon (Falco peregrinus) populations recovered globally after a dramatic decline experienced between the 1950s and 1980s. The conservation challenge forced the raptor biologist community to co-operate internationally. As a part of the co-operation, four conferences were organised to identify the problem, coordinate conservation efforts including research and to monitor the recovery process of the species' populations worldwide. The line of conferences started in Madison (WI, USA) in 1965 and was followed by two conferences in Sacramento (CA, USA) and Piotrowo/Poznan (Poland) in 1985 and in 2007, respectively. The latest conference was organised in 2017, in Budapest, where Peregrine experts discussed the latest research and monitoring results. The event provides a good occasion to review the development of the Peregrine population in Hungary. The species became extinct in Hungary as a breeding species in the mid-1960s due to the intensive use of pesticides (DDT) and it returned only in 1997, when the first successful breeding was recorded. In 2018, 72 active eyries were recorded. The Hungarian population is the edge of the Carpathian Peregrine population and the birds represent mostly the nominate subspecies (F. p. peregrinus), but individuals showing typical phenotype of the Mediterranean subspecies (F. p. brookei) were also observed. The northern race of F.p. calidus also occurs on migration and in winter. The Hungarian population is sedentary. Natal dispersal of females is biased to males, but in case of both sexes most ring recoveries of adult birds occurred within the Pannonian basin. The increasing Peregrine population expanding to the lowland may cause conservation conflict on medium term by competing with the endangered Saker Falcon (Falco cherrug) for the nest sites. The conservation status of the Peregrine Falcon in Hungary is good in general, but threats may emerge on local scale in some regions. No specific conservation measures are taken, research and monitoring focus on population changes and threats posed on and caused by Peregrines.
\end{abstract}

Keywords: population recovery, subspecies, diet, movements, Falco cherrug

Összefoglalás Az 1950-es és az 1980-as évek közötti időszakban tapasztalt összeomlás után a vándorsólyom (Falco peregrinus) világszerte regenerálódott. A természetvédelmi kihívás nemzetközi összefogást kényszerített ki a ragadozómadarakkal foglalkozó biológusok között. Ennek az összefogásnak a részeként négy konferencia került megrendezésre a probléma feltárásának, a kutatások és a védelmi erőfeszítések összefogásának, valamint az állományok regenerációjának világszerte történő nyomon követésének érdekében. A konferenciasorozatban az első az 1965-ös madisoni (Wisconsin állam, USA) konferencia volt, amelyet két konferencia követett Sacramentoban (Kalifornia) és Pietrowo/Poznańban (Lengyelország), 1985-ben és 2007-ben. A sorozat legutóbbi konferenciája 2017-ben Budapesten került megrendezésre, ahol a vándorsólyommal foglalkozó szakemberek megvitathatták a legfrissebb kutatási és monitoring eredményeket. Az esemény jó alkalmat kínált arra, hogy áttekintsük a vándorsólyom állományának változását Magyarországon. Mint fészkelő faj kipusztult Magyarországról a hatvanas évek közepén, az intenzív növényvédöszer-használatnak (DDT) köszönhetően, és csak 1997-ben tért vissza. Akkor figyelték meg ismét sikeres fészkelését az országban. 2018-ban 72 aktív revírt ismerünk. A magyar állomány a Kárpátokban fészkelő állomány peremének tekinthető, és túlnyomórészt a törzsalakhoz (F. p. peregrinus) tartozik. Megfigyeltek azonban fészkelésben a mediterrán alfajhoz (F. p. brookei) tartozó egyedeket is. Az északi 
alfaj F. p. calidus is előfordul vonuláskor, illetve télen. A magyar költőállomány állandó. A diszperzió a tojóknál nagyobb, mint a hímeknél, de mindkét ivar esetében az ivarérett madarak gyưrüzési megkerülései túlnyomórészt a Kárpát-medence területéről származnak. A növekvő és az alföldi területek felé terjeszkedő vándorsólyom állomány természetvédelmi problémát jelenthet középtávon, amennyiben a veszélyeztetett kerecsensólyom (Falco cherrug) fészekkompetítora lesz. A vándorsólyom természetvédelmi helyzete Magyarországon általában jó, de helyi szinten merülhetnek fel problémák bizonyos régiókban. Nincs szükség specifikus védelmi intézkedésre. A kutatás és a monitoring az állomány változásait, valamint a veszélyt jelentö tényezőket vizsgálja. Emellett figyelmet szentel a vándorsólyom által okozott problémáknak is.

Kulcsszavak: állománynövekedés, alfaj, táplálék, elmozdulások, Falco cherrug

${ }^{1}$ Herman Ottó Institute Nonprofit Kft., 1223 Budapest, Park utca 2., Hungary

${ }^{2}$ BirdLife Hungary, 1121 Budapest, Költö utca 21., Hungary

*corresponding author: prommerm@hoi.hu

\section{Introduction}

The recovery of the Peregrine Falcon is a conservation success story: during a few decades the global - more accurately Eurasian and North American - population recovered beyond any expectation. The species' population came back from a devastating decline caused by DDT and other pesticides in the early $2^{\text {nd }}$ half of the $20^{\text {th }}$ century. The road to success, however required international cooperation, which can be best characterized by the four conferences dedicated to the species. The conference held in Madison, Wisconsin, U.S. in 1965 aimed to unveil the possible causes of the disastrous population decline in North America and Europe. The international effort was successful and the so far widely used DDT has been banned in most countries in the world. Three other conferences followed the historic Madison Conference: in Sacramento, USA (1985), in Piatrowo/Poznań, Poland (2007) and in Budapest, Hungary (2017). They summarized the latest knowledge on the species including follow-up of the recovery process, monitoring populations, describing behaviour, introducing new challenges in conservation and proposing conservation management methods.

The last conference confirmed again that the species has well recovered, and the population has been stable or grown even in the last ten years (Beran et al. 2018, Brunelli \& Saccoro 2018, Zuberogoitia et al. 2018). Apart from natural expansion to ancient nesting sites, re-introduction programmes aim to bring back the tree-nesting populations in the plains of Poland (Sielicki \& Sielicki 2017) and Russia (Pazhenkov et al. 2018). In other cases, populations are stable (Pasquier et al. 2018) or follow the changes of distribution patterns of prey species (Nygård \& Reinsborg 2017). In some parts of the European distribution range, however, the recovery process was followed recently by a decline (Kéry et al. 2018, Monneret et al. 2018).

The rapidly growing, viable Peregrine populations may also cause conflicts with other species as they occupy new habitats (Prommer et al. 2017, De Rosa et al. 2018) and outcompete other large falcons of which diet spectre narrowed down to avian prey (Bondì et al. 2017). Of course, conservation problems were also at stake like deliberate poisoning (Inderwildi et al. 2018). 
The Budapest Peregrine conference gave us the possibility to summarize also the information about the Hungarian population with special regard on the period since the last internationally published article (Bagyura et al. 2009, Prommer 2009).

\section{Dynamics of Peregrine Falcon population in Hungary}

Monitoring of falcon populations started in the late $10^{\text {th }}$ century when the first Hungarian tribes - practicing falconry - arrived in the Carpathian Basin. Names of geographic locations, cliffs, settlements, medieval poems and trading agreements prove the importance of falcons up to the Modern History (Csőre 1996). Traditional hunting methods like falconry became outdated with the spread of firearms and instead of allies, hunters started to see competitors in birds of prey, which resulted in a long-lasting persecution of raptors. As a result, only a fragment of the original raptor populations remained in Hungary and even them withdrew into the hills and mountains, where large game keepers were uninterested in them. It was only in 1949-1950, when Pátkai and Bástyai carried out a countrywide survey, where they found only 18 Peregrine Falcon eyries in Hungary (Pátkai 1951). DDT, however, took its toll also in Hungary and the last recorded successful breeding was in 1964, when nestlings were removed from the nest to be taken to the Budapest Zoo and Saker Falcons (Falco cherrug) occupied the empty Peregrine eyries (Bagyura et al. 2009, Prommer et al. 2009).

Through 33 years, Peregrine was absent from Hungary as a breeding species. From the early 1990s' observations, Peregrines became more frequent and finally the first breeding took place in Pilis-Visegrádi Hills in 1997: the Peregrine Falcon returned to Hungary (Bagyura 1997). They have gradually taken back the ancient eyries in the hills and mountains. The number of Peregrine pairs remained low in the first ten years, but in 2007 the population started to grow rapidly, and increased to sixfold by 2017 from 12 (2007) to 72 (2018) occupying pairs (Figure 1), but the population growth slowed down in 2015. The recovery process was similar to the recovery of Peregrine populations for example in the Czech Republic (Beran et al. 2018) or in Denmark (Andreasen et al. 2018). The reasons of decreasing growth rate of the Hungarian population is not exactly known. One possible reason is

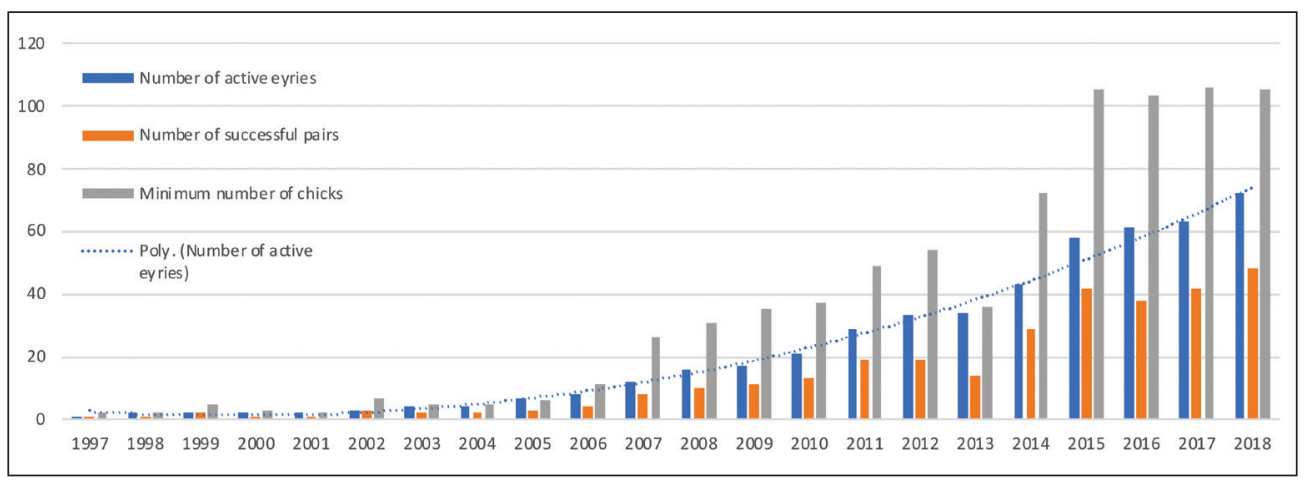

Figure 1. The dynamics of Peregrine Falcon population in Hungary between 1997-2018

1. ábra A magyarországi vándorsólyom-állomány változása 1997 és 2018 között 


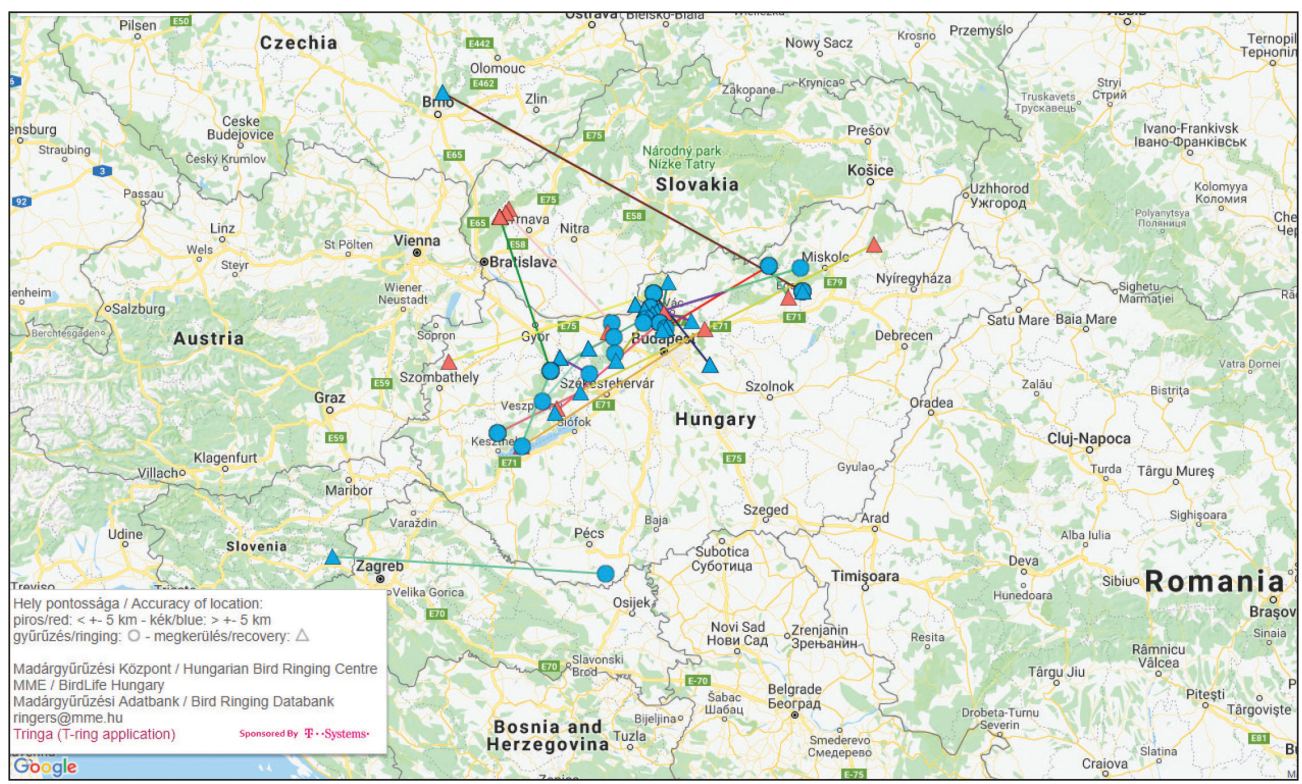

Figure 2. Ring recoveries of Hungarian-ringed (breeding adult - triangles, pullus - dots) Peregrine Falcons

2. ábra A Magyarországon fiókaként gyűrűzött (kör) és költésben megkerült (háromszög) vándorsólymok megkerülései

that Hungary is not very rich in natural cliffs and quarries, and the best quality ones have already been taken by Peregrines or Eagle Owls (Bubo bubo). It can also be an indication of a population decline in the coming years as it occurred in Northern Spain (Zuberogoitia et al. 2018), in Switzerland (Kéry et al. 2018) and in France (Monneret et al. 2018).

The bulk of the Hungarian population distributed across the Transdanubian and Northern Hills represents the $F$. peregrinus peregrinus subspecies and can be considered as the edge of the Carpathian population (Slovakia) as ring recoveries proved (Figure 2). We suspect however, that in South and West Hungary, individuals belonging to F. peregrinus brookei may also occur (Bagyura et al. 2008). It is likely that Hungary falls in the range where the two subspecies mix, similarly to northern Spain, where typical F. p. peregrinus and $F$. $p$. brookei, as well as many forms of intermediate phenotypes can be observed in a few hundred kilometre broad zone (Zuberogoitia et al. 2009). Genetic analyses also confirm and explains phenotypical diversity in those zones (Mengoni et al. 2018).

\section{Habitats}

Peregrines do not build their own nest but occupy nests of other species or they simply lay their eggs on ledges of cliffs. In addition to natural cliffs and rock formations, they occupy also abandoned or operating quarries. They prefer nest sites close to open areas like large water bodies or arable land, and they need forested areas hosting breeding passerine species. 
According to their preferences, Peregrines can be found mostly in hills and mountainous areas in Hungary. As the population expanded however, new pairs appeared also on the edges of the Hungarian plains, in new habitats, where Peregrines were not present earlier as breeding species. They learnt to use nest boxes on pylons of high voltage power lines installed for Saker Falcons (Prommer \& Bagyura 2017). We closely monitor all pairs breeding on pylons by using camera traps to identify any colour ringed individuals. Photos of camera traps showed that in all pairs there is at least one colour-ringed individuals fledged from cliff nests in Hungary. That shows a high plasticity of the species in choosing nest site. In 2018, there were seven known pairs on pylons and five of them bred successfully fledging thirteen juveniles.

The next phase of population growth is expected when Peregrines start to occupy cities in Hungary. Unlike in most European and North American cities, there are no record of Peregrine breeding in Budapest or in any other Hungarian city. The first city breeding Peregrines are expected to settle in Budapest, considering available food, nesting possibilities, as well as the dense Peregrine population in its neighbourhood. The Hungarian capital alone could host a minimum of 3-4 breeding pairs. Other cities close to areas with saturated Peregrine populations are potential areas of expansion. Wintering falcons regularly use cities, proving that the habitat can maintain falcons, thus we could expect that Peregrine will inhabit cities. At the same time, wintering falcons - staying in Hungary as long as untill April - may prevent local Peregrines to occupy the best quality habitats in cities in late winter - early spring and form new pairs. The interactions between the two populations still unknown and require more research.

Migrating and wintering Peregrines form a separate population in Hungary (Prommer 2005, Prommer et al. 2009). Satellite-tracking studies (Dixon et al. 2012, Sokolov et al. 2018, Váczi unpubl.) suggest that Peregrines migrating across and wintering in Hungary originate from northwest Russia. A few observations (Bagyura pers. comm.) indicate that the subspecies F. p. calidus also may occur in Hungary in the migration and wintering period. Observations on Peregrines (birding.hu) show a double-peak - autumn and spring - distribution, which signals that a larger number of birds migrate across Hungary. A number of "foreign" individuals, however winter in larger cities of Hungary using high building, cathedrals, churches and towers, as well as industrial complexes, as perch sites. Almost all city wintering birds are females and they usually remain until late spring (April).

\section{Migration and other movements}

According to observations and ring recoveries, most of the breeding pairs are sedentary and stay in their eyries through all year; or move to an area with abundant prey in the vicinity of the nest site. That movement can be best described as short distance altitudinal 'migration' and it covers the movement of the Peregrines descending from the hills (nest site) to foothills or plains (foraging site) within a few kilometres.

Juveniles usually roam across the Pannonian basin and they even may cross the Carpathians (Figure 3) as satellite tracking data (Prommer et al. 2009) and ring recoveries show. 


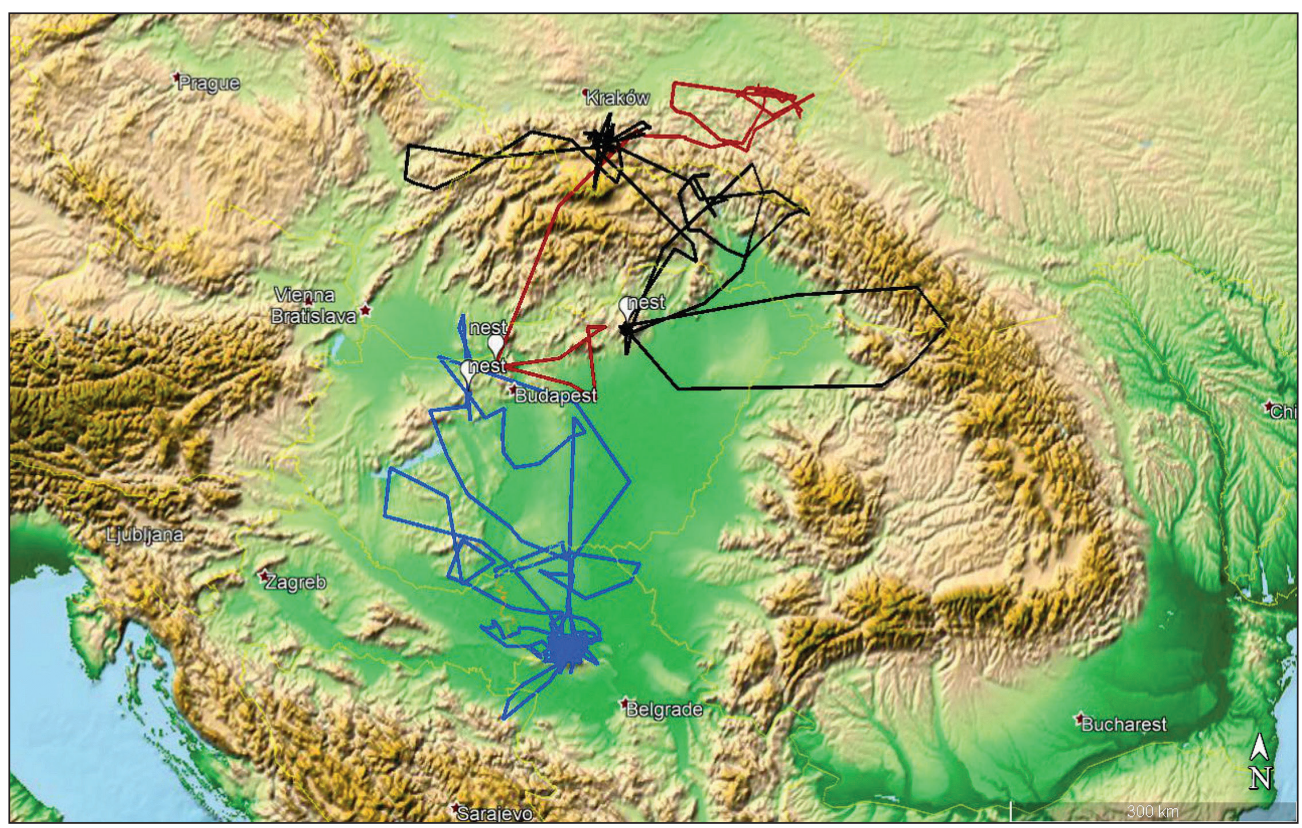

Figure 3. Movements of three satellite tracked juveniles tagged in nest before fledging (2009-2010) 3. ábra Három, kirepülés előtt fészekben jelölt fiatal vándorsólyom mozgásai (2009-2010)

Natal dispersal follows the well-known pattern (Greenwood 1980, Clarke et al. 1997, Faccio et al. 2013) and males settle closer to the fledging site than females. The values are $177.9 \mathrm{~km}$ for males $(\mathrm{n}=23)$ and $212.9 \mathrm{~km}$ for females $(\mathrm{n}=19)$ based on the ring recoveries of breeding adults ringed in Hungary (source: Hungarian Bird Ringing Centre). Females of Hungarian origin were identified at nests by their colour rings in Slovakia (3), the Czech Republic (1) and Slovenia (1). Ring recoveries of breeding males restricted so far to Hungary.

\section{Diet}

Prey species in Peregrines' diet in the breeding season were identified from remains collected in nests and on photos taken by camera traps set on active nests. Despite the fact that Peregrines take avian prey almost exclusively, their diet is diverse, and many bird species can be found in the species list (Ratcliffe 1993, Rockenbauch 1998). The absolute favourite prey is the Feral Pigeon (Columba livia f. domestica), followed by Starling (Sturnus vulgaris) and Hawfinch (Coccothraustes coccothraustes). The presence of latter in the diet however, noticeably decreased in the last few years. Apart from those species, remains of Great Woodpeckers (Dendrocopos major), Green Woodpeckers (Picus viridis), Grey-headed Woodpeckers (Picus canus), Blackbirds (Turdus merula) can be regularly seen in nests, but sometimes rarities like Golden Oriole (Oriolus oriolus) or even escapees like Budgerigar (Melopsittacus undulatus) were found. Apart from birds, a bat species, the Common Noctule (Nyctalus noctula) were also relatively common prey. Unsurprisingly, forest-dwelling 
species dominate the list beside pigeons, which reflects the habitats, in which most Peregrines nests can be found. The prey list is certainly longer, however, no species list is available on preys of Hungarian Peregrines caught outside of the breeding season. In comparison, a northern Peregrine wintering through eleven years in Hungary lists 34 prey species (Kocsis \& Prommer 2017). An important difference in diet between local and northern, wintering Peregrines that in the diet of latter wetland birds - waders and waterfowl - can be found in higher proportion (Prommer et al. 2009). The difference resulted from the different habitat they use: wintering birds usually establish their wintering eyries near or in wetland areas, where local birds are more tied to hills and forests. As opportunistic predators, Peregrines use available food sources highly efficiently, as recent studies suggest (Dixon \& Drewitt 2018, Dixon et al. 2018).

\section{Threats}

We found sharpened wires twisted around pigeons' legs in Peregrine nests signalling someone's intention to kill birds of prey. Several sources also confirmed that some pigeon-fanciers use illegal methods to kill Peregrines and other birds of prey hunting on pigeons. A differentiation must be made between Homing Pigeons and high-flyers. Homing Pigeons are being released in large numbers when training or in competition and Peregrines, Saker Falcons, Goshawks (Accipiter gentilis) and Sparrowhawk (Accipiter nisus) target them. High-flyers, however, have been bred for flying circles in close flocks high above their home and remain up in the air for long time. Ideal targets for Peregrines. While most of the raptor attacks on Homing Pigeons remains unseen for obvious reasons, attacks on high-flyers are regularly seen by breeders inducing strong emotional reactions. It must be noted, however, that the main problem of breeders is not the loss of a pigeon, but that Peregrines spoil the competition, in which they invested considerable money, because the flock disintegrates, and the pigeons land much earlier than they suppose to. As Peregrine population evolved, pigeon-fanciers ceased breeding high-flyers in some parts of Hungary. In other areas, they still use illegal methods to eliminate falcons attacking their flocks (Inderwildi et al. 2018).

Accidental or deliberate human disturbance is a major threat on breeding success. As Hungary does not have many cliffs, the few ones are tourist destinations with a visitors' peak in spring. Established pairs are usually very tolerant, but volunteer nest guarding is organised for the most sensitive sites.

Illegal take of chicks from nest are officially recorded only in 2018, when a camera trap set on a nest recorded a man climbing down to the nest and taking away two nestlings. Indirect signs however, suggested that similar actions were done at other nests as well in the previous years.

Electrocution and collision to wires or buildings must be also counted as a threat on Peregrines, which affects mostly the inexperienced juvenile birds.

Every year one or two juvenile Peregrines are reported to be caught in pigeon houses or in the loft. They followed the pigeons there and could not make their way out. The real number is probably higher and not all the birds survive the mistake they made. 


\section{Conservation and research}

The Peregrine population in Hungary is growing and also considering international trends, no extra conservation measures are necessary apart from local measures to protect endangered breeding. We do annual monitoring of recent and former breeding sites, we follow the changes in the population, ring and colour ring the chicks, install camera traps on nests, make problematic nest sites safe and organise nest guarding where it is necessary.

We closely follow the evolution of pylon-nesting pairs especially that those type of population expansion may conflict the Saker Falcon conservation interests.

Public awareness raising is also part of the work, e.g. Peregrine Falcon was the "Bird of the Year" in 2018 and the species was highlighted in the media.

\section{Acknowledgement}

Hereby we want to thank the invaluable support in Peregrine conservation work to: Attila Bartha, Csaba Bartha, András Békefi, István Béres, Péter Csonka, László Darányi, Iván Demeter, Szabolcs Farkasł’, Gyula Gábor, Csaba Gémesi, László Haraszthy, Krisztián Harmos, Krisztián Harsányi, Gábor "Gabban” Horváth, Evelin Illyés, Róbert Kazi, Antal Klébert, Krisztián Korcsog, András Kovács, Dénes Laczik, Gábor Magos, István Lotár Molnár, Márton Molnár, Dr. Lajos Nagy, Adrián Novák, Ferenc Papp, Ádám Pongrácz, István Rottenhoffer, Tibor Sárog†, Nándor Seres, József Serfőző, Gábor Sinka, Csaba Spilák, Béla Solti, István Staudinger, Péter Szinai, Tamás Szitta, Barna Tarján, Imre Tóth, Miklós Váczi, Levente Viszló. In addition, we are grateful to the staff of Aggtelek National Park Directorate, Bükk National Park Directorate, Danube-Ipoly National Park Directorate, Balaton Upland National Park Directorate, Danube-Dráva National Park Directorate, MAVIR Corp., Mátrai Power Plant Corp. and Pilis Nature Conservation Association for their full support.

\section{References}

Andreasen, N. P., Falk, K. \& Møller, S. 2018. The Danish Peregrine Falcon population: Reestablishment and eggshell thinning. - Ornis Hungarica 26(2): 159-163. DOI: 10.1515/orhu-2018-0024

Bagyura, J. 1997. A vándorsólyom (Falco peregrinus) fészkelése Magyarországon a XX. században [Breeding records of Peregrine Falcon (Falco peregrinus) in Hungary in the $20^{\text {th }}$ century]. - Túzok 2(4): 129-135. (in Hungarian with English Summary) http://www.mme.hu/sites/default/files/binary_uploads/tudastar/tuzok/tuzok_1997.pdf

Bagyura, J., Prommer, M., Nagy, L., Váczi, M., Molnár, I. L., Szitta, T., Viszló, L. \& Fatér, I. 2008. A vándorsólyom dél-európai alfajának (Falco peregrinus brookei) sikeres költése Magyarországon a kezdetektől napjainkig [Successful breeding of the Mediterranean subspecies of Peregrine Falcon (Falco peregrinus brookei) from the beginning until recently]. - Heliaca 2008: 48-52. (in Hungarian) http://www.mme.hu/binary_uploads/2_magunkrol/heliaca/heliaca_2008_online.pdf

Bagyura, J., Prommer, M., Szitta, T., Molnár, I. L. \& Kazi, R. 2009. Status of Peregrine population in Hungary 1964-2007. - In: Mizera, T. \& Sielicki, J. (eds.) Peregrine Falcon Populations - Status and Perspectives in the $21^{\text {st }}$ century. - Turul Publishing, pp. 51-61.

Beran, V., Vrána, J. \& Horal, D. 2018. Population trends and diversification of breeding habitats of Peregrine Falcon (Falco peregrinus) in the Czech Republic since 1990. - Ornis Hungarica 26(2): 121-129. DOI: 10.1515/ orhu-2018-0020 
Brunelli, M. \& Sarrocco, S. 2018. Breeding population of Peregrine Falcon (Falco peregrinus) in Lazio, Central Italy: 1983-2017. - Ornis Hungarica 26(2): 114-120. DOI: 10.1515/orhu-2018-0019

Bondì, S., Vitale, E., Antioco, N., Guzzo, E., Schifani, E., Mascara, R. \& Sarà, M. 2017. Comparative analysis of Lanner and Peregrine trophic niche in the Mediterranean. - In: $4^{\text {th }}$ International Peregrine Conference, Budapest, pp. 26. (abstract) http://peregrinus.pl/files/peregrine_conference_2017/4th_peregrine_Conference_Abstact_book_web.pdf

Clarke, A. L., Saether, B-E. \& Røskaft, E. 1997. Sex biases in avian dispersal: a reappraisal. - Oikos 79(3): 429438. DOI: $10.2307 / 3546885$

Csőre, P. 1996. A solymászat története [The history of falconry]. - Terraprint Kiadó, Budapest (in Hungarian)

De Rosa, D., Di Febbraro, M., De Lisio, L., De Sanctis, A. \& Loy, A. 2018. The decline of the Lanner Falcon in Mediterranean landscapes: Competition displacement or habitat loss? - Animal Conservation DOI: 10.1111/ acv. 12430

Dixon, A., Sokolov, A. \& Sokolov, V. A. 2012. The subspecies and migration of breeding Peregrines in northern Eurasia. - Falco 39: 4-9.

Dixon, A., Richards, C. \& King, A. V. 2018. Diet of Peregrine Falcons (Falco peregrinus) in relation to temporal and spatial variation in racing pigeon availability in Wales. - Ornis Hungarica 26(2): 188-200. DOI: 10.1515/ orhu-2018-0028

Dixon, N. \& Drewitt, E. J. A. 2018. A 20-year study investigating the diet of Peregrines, Falco peregrinus, at an urban site in south-west England (1997-2017). - Ornis Hungarica 26(2): 177-187. DOI: 10.1515/orhu-2018-0027

Faccio, S. D., Amaral, M., Martin, C. J., Lloyd, J. D., French, T. W. \& Tur, A. 2013. Movement patterns, natal dispersal and survival of Peregrine Falcons banded in New England. - Journal of Raptor Research 47(3): 246-261. DOI: $10.3356 / J R R-12-21.1$

Greenwood, P. J. 1980. Mating systems, philopatry and dispersal in birds and mammals. - Animal Behaviour 28(4): 1140-1162. DOI: 10.1016/S0003-3472(80)80103-5

Inderwildi, E., Müller, W., Ayé, R. \& Sinniger, M. 2018. A summary of intentional poisoning of Peregrine Falcons in Switzerland during the last decade. - Ornis Hungarica 26(2): 164-170. DOI: 10.1515/orhu-2018-0025

Kéry, M., Banderet, G., Neuhaus, M., Weggler, M., Schmid, H., Sattler, T. \& Parish, D. 2018. Population trends of the Peregrine Falcon in Switzerland with special reference to the period 2005-2016. - Ornis Hungarica 26(2): 91-103. DOI: 10.1515/orhu-2018-0017

Kocsis, S. \& Prommer, M. 2017. Egy északi vándorsólyom (Falco peregrinus) telelése Dél-Magyarországon 2006 és 2017 között [Wintering of a northern Peregrine Falcon (Falco peregrinus) in South-Hungary between 2006 and 2017]. - Heliaca 2017. in print (in Hungarian) http://www.mme.hu/binary_uploads/2_magunkrol/heliaca/ heliaca_2017_online.pdf

Mengoni, C., Zuberogoitia, I., Mucci, N., Boano, G., Urban, T., Guzzo, E. \& Sarà, M. 2018. Genetic variability in Peregrine Falcon populations of the Western Palaearctic region. - Ornis Hungarica 26(2): 12-26. DOI: 10.1515/ orhu-2018-0012

Monneret, R-J., Ruffinoni, R., Parish, D., Pinaud, D. \& Kéry, M. 2018. The Peregrine population study in the French Jura mountains 1964-2016: use of occupancy modeling to estimate population size and analyze site persistence and colonization rates. - Ornis Hungarica 26(2): 69-90. DOI: 10.1515/orhu-2018-0016

Nygård, T. \& Reinsborg, T. 2017. Increasing Peregrine population in central Norway shifting from the coast to the inland - a 40-year study. - In: $4^{\text {th }}$ International Peregrine Conference, Budapest, p. 32. (abstract) http://peregrinus. pl/files/peregrine_conference_2017/4th_peregrine_Conference_Abstact_book_web.pdf

Pasquier, Ch., Fehlmann, M., Bresson, Ch., Fremaux, S., Jean, A. \& Thelliez, J-P. 2018. Monitoring of Peregrine Falcons in the Pyrenees and Toulouse, Midi-Pyrénées region, France. - Ornis Hungarica 26(2): 143-158. DOI: 10.1515/orhu-2018-0023

Pazhenkov, A., Karyakin, I., Afanasyev, D., Krivopalova, A. \& Pazhenkova, E. 2018. To restoration of the tree-nesting Peregrine Falcon (Falco peregrinus) population in the Volga-Ural Region. - Ornis Hungarica 26(2): DOI:

Pátkai, I. 1951. Ragadozómadár-kutatások az 1949. és 1950. években [Birds of prey surveys in 1949 and 1950]. Aquila 55-58: 75-77.

Prommer, M. 2005. Gondolatok a vándorsólyom költési időszakon kívüli előfordulásához Magyarországon [Thoughts about the presence of Peregrine Falcons in Hungary outside of the breeding season]. - Heliaca 2005: 74-83. (in Hungarian)

Prommer, M. 2009. Peregrines in Hungary breeders, migrants, winter and summer visitors. - In: Mizera, T. \& Sielicki, J. (eds.) Peregrine Falcon Populations - Status and Perspectives in the $21^{\text {st }}$ century. - Turul Publishing, pp. 215-229. 
Prommer, M., Bagyura, J., Molnár, I. L., Gallai, G., Szitta, T., Viszló, L., Kazi, R. \& Csonka, P. 2009. A Vándorsólyom-védelmi Munkacsoport 2009. évi beszámolója [Report of the Peregrine Falcon Conservation Working Group 2009]. - Heliaca 2009: 49-55. (in Hungarian) http://www.mme.hu/binary_uploads/2_magunkrol/heliaca/heliaca_2009_online.pdf

Prommer, M. \& Bagyura, J. 2017. Peregrine Falcon (Falco peregrinus) vs. Saker Falcon (Falco cherrug) in Hungary - Competitors or not? - In: $4^{\text {th }}$ International Peregrine Conference, Budapest, pp. 26. (abstract) http://peregrinus.pl/files/peregrine_conference_2017/4th_peregrine_Conference_Abstact_book_web.pdf

Ratcliffe, D. 1993. Peregrine Falcon. - Princeton University Press, $2^{\text {nd }}$ ed.

Rockenbauch, D. 1998. Der Wanderfalke in Deutschland, Band 1-2. [The Peregrine Falcon in Germany, Vol. 1-2.]. - C. Hölzinger, Ludwigsburg, Annex (in German)

Sokolov, V., Sokolov, A. \& Dixon, A. 2018. Migratory movements of Peregrine Falcons Falco peregrinus, breeding on the Yamal Peninsula, Russia. - Ornis Hungarica 26(2): 222-231. DOI: 10.1515/orhu-2018-0030

Sielicki, J. \& Sielicki, S. 2017. Falconry and restoration of Peregrine Falcon population in Poland 1990-2017. - In: $4^{\text {th }}$ International Peregrine Conference, Budapest, pp. 26. (abstract) http://peregrinus.pl/files/peregrine_conference_2017/4th_peregrine_Conference_Abstact_book_web.pdf

Zuberogoitia, I., Azkona, A., Zabala, J., Astorkia, L., Castillo, I., Iraeta, A., Martínez, J. A. \& Martínez, J. E. 2009. Phenotypic variations of Peregrine Falcon in subspecies distribution border. - In: Mizera, T. \& Sielicki, J. (eds.) Peregrine Falcon Populations - Status and Perspectives in the $21^{\text {st }}$ century. - Turul Publishing, pp. 295-309.

Zuberogoitia, I., Morant, J., Castillo, I., Martínez, J. E., Burgos, G., Zuberogoitia, J., Azkona, A., Guijarro, J. R. \& González-Oreja, J. A. 2018. Breeding trends of Peregrine Falcon in Northern Spain - Results of a long-term monitoring project. - Ornis Hungarica 26(2): 51-68. DOI: 10.1515/orhu-2018-0015

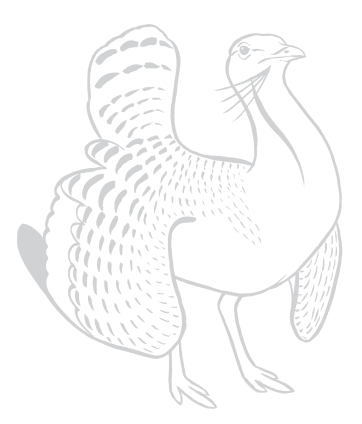

